\title{
Outcomes of Renal Transplantation in Brunei Darussalam over a Twenty-Year Period (1993-2012)
}

\author{
Jackson Tan, ${ }^{1}$ Muhammad Abdul Mabood Khalil, ${ }^{2}$ Si Yen Tan, ${ }^{3}$ Muhammad Khalil, ${ }^{1}$ \\ Dalinatul Ahmed, ${ }^{1}$ Shaukat Zinna, ${ }^{1}$ and William Chong ${ }^{1}$ \\ ${ }^{1}$ RIPAS Hospital, Bandar Seri Begawan BA1710, Brunei Darussalam \\ ${ }^{2}$ Aga Khan University Hospital, Karachi 74800, Pakistan \\ ${ }^{3}$ Prince Court Medical Centre, 50450 Kuala Lumpur, Malaysia \\ Correspondence should be addressed to Jackson Tan; drjacksontan@yahoo.co.uk
}

Received 11 July 2014; Revised 19 October 2014; Accepted 22 October 2014; Published 12 November 2014

Academic Editor: Kazuhiko Yamada

Copyright (C) 2014 Jackson Tan et al. This is an open access article distributed under the Creative Commons Attribution License, which permits unrestricted use, distribution, and reproduction in any medium, provided the original work is properly cited.

\begin{abstract}
Objectives. Brunei Darussalam has a high prevalence and incidence of end stage renal disease (ESRD). Up until 2012, all renal transplantations were performed in overseas centres, either as government-sponsored (living-related transplantation) or as selfsponsored (commercialized transplantation) ones. We hypothesize that graft and patient survival of Brunei renal transplant patients are on a par with international standards. Materials and Methods. Data of all renal transplant patients in Brunei were analysed over a twenty-year period from registry records and case notes. Comparative survival data from other countries were obtained from PubMed-listed literature. Results. A total of 49 transplantation procedures were performed in foreign centres between 1993 and 2012. 29 were government-sponsored and 20 were self-sponsored transplantations. The 5- and 10-year overall patient survival rates were $93.3 \%$ and $90.1 \%$, respectively. The 5 - and 10 -year overall graft survival rates were $91.1 \%$ and $81.2 \%$. There is no difference in the survival outcomes of government-sponsored and self-sponsored patients. Living-related (government-sponsored) and commercialised (self-sponsored) grafts had equivalent survival to those reported in the literature. Conclusion. Our survival data was on par with those achieved in many countries. We hope to use this information to convince local stakeholders and patients to favour transplantation as the preferred modality of RRT.
\end{abstract}

\section{Background}

Brunei Darussalam has a high prevalence and incidence of end stage renal disease (ESRD). Data from the 1st Brunei Dialysis and Transplant Registry (BDTR) revealed a prevalence and incidence of 1250 and 265 per million population (pmp), respectively, in 2011 [1]. Renal transplantation is a poorly utilised and accepted modality of renal replacement therapy (RRT) in Brunei. At the end of 2012, only 6\% of the existing RRT population had a functioning transplant graft [2]. The discrepancy between the high prevalence of ESRD and low prevalence of renal transplantation has led to overdependence on haemodialysis (HD) and peritoneal dialysis (PD) therapy. Eligible ESRD patients desirous of having a renal transplant, and their screened and matched relatives, are sent under government sponsorship to endorsed overseas centres for living-related transplant operations. This practice has been increasingly prevalent in the last twenty years, especially with the growing pool of eligible ESRD patients, improving transplant awareness and the absence of a local transplant program. In addition, there are a substantial number of noneligible patients (usually those without suitable kidney donors) who go overseas for commercialised and non-government-sponsored transplantations.

A local living-related transplant program was started in Brunei in 2013 [3]. The main motivations behind starting the program are to provide care for patients in their local environment and to deter commercialised overseas transplantations. At present, there is no cadaveric transplant program in Brunei. As the program is still at its infancy, there is a limit to the number of transplants that can be performed due to the lack of resources, expertise, and facilities. Patients are still 
TABLE 1: Demographic details of transplant patients.

\begin{tabular}{|c|c|c|c|c|}
\hline & Total & Government-sponsored & Self-sponsored & $P$ value \\
\hline Number & 49 & 29 & 20 & \\
\hline Median age (years) & 31 & 32 & 37 & \\
\hline \multicolumn{5}{|l|}{ Sex } \\
\hline Male & 32 & 16 & 16 & \multirow{2}{*}{$>0.05$} \\
\hline Female & 17 & 13 & 4 & \\
\hline \multicolumn{5}{|l|}{ Relationship to recipient } \\
\hline Spouse & 9 & 9 & 0 & \multirow{3}{*}{$<0.001$} \\
\hline Relatives & 20 & 20 & 0 & \\
\hline Unknown & 20 & 0 & 20 & \\
\hline \multicolumn{5}{|l|}{ Aetiology } \\
\hline Diabetes mellitus & 3 & 1 & 2 & \multirow{5}{*}{$P>0.05$, for trend } \\
\hline Hypertension & 2 & 1 & 1 & \\
\hline Glomerulonephritis & 23 & 15 & 8 & \\
\hline Others & 3 & 2 & 1 & \\
\hline Unknown & 18 & 10 & 8 & \\
\hline \multicolumn{5}{|l|}{ Race } \\
\hline Malay & 37 & 27 & 10 & \multirow{2}{*}{0.014} \\
\hline Chinese & 12 & 2 & 10 & \\
\hline \multicolumn{5}{|c|}{ Place where transplant was performed } \\
\hline Singapore & 29 & 28 & 1 & \multirow{5}{*}{$P>0.05$, for trend } \\
\hline Malaysia & 2 & 2 & 0 & \\
\hline China & 9 & 0 & 9 & \\
\hline India & 7 & 0 & 7 & \\
\hline Others & 2 & 0 & 2 & \\
\hline
\end{tabular}

being sent abroad as demand is outstripping the capability of the local transplant centre. While waiting for the local program to mature, the country will continue to be reliant on government-sponsored overseas transplant in the immediate future. In doing so, extra justifications to support the costeffectiveness and safety of this practice are needed, which has provided the impetus for this study to be undertaken.

We hypothesize that graft and patient survival of Brunei transplant patients performed overseas are on a par with international acceptable standards. The research also enables us to review our renal transplantation practice and trend in Brunei Darussalam over the last twenty years (1993 to 2012).

\section{Methods and Objectives}

We analysed data of all renal transplant patients in Brunei over a twenty-year period (between 1993 and 2012). Data collection was performed through the combination of the use of registry data, patients' case notes, and old department records. The data collected included age at transplant, gender, aetiology of primary renal disease, country of transplant, date of transplant, date of death (if applicable), and date of graft failure. For the ease of comparisons, we divided the patients into two groups: government-sponsored patients and self-sponsored (commercialised) patients. Comparative data from other countries were obtained from the PubMedlisted literature. Statistical analysis on survival outcomes was performed using Kaplan-Meier survival analysis on PASW
Statistics 18 software. Fisher's test was used for statistical analysis of demographic data.

\section{Results}

A total of 49 transplantation procedures were performed on 47 patients between 1993 and 2012. All the procedures were performed in foreign centres. There was male preponderance $(65 \%)$, especially in the self-sponsored population. The most common aetiological diseases for transplant patients were glomerulonephritis (47\%), diabetes mellitus (6\%), and hypertension (4\%). All self-sponsored patients received kidneys from unrelated sources. Chinese patients were more likely to have self-sponsored transplantation $(P<0.05)$ than government-sponsored transplantation. Most of our transplanted patients (49\%) had their surgeries performed in Singapore. The demographic details of these patients are illustrated in Table 1. Transplantations performed in the earlier part of the researched period (1993-2000) were mainly selfsponsored. However, there appeared to be a trend towards government-sponsored transplantation in the last decade. The incidence of government-sponsored and self-sponsored transplantations between 1993 and 2012 is summarised in Table 2.

The 5- and 10-year patient survival rates were $93.3 \%$ and $90.1 \%$, respectively (Figure 1 ). The 5 - and 10 -year graft survival rates were $91.1 \%$ and $81.2 \%$ (Figure 2 ). The 5 - and 10 year graft survival rates for government-sponsored patients 
TABLE 2: Incident cases of government-sponsored and selfsponsored transplantations between 1993 and 2012.

\begin{tabular}{lccc}
\hline Time period & $\begin{array}{c}\text { Government- } \\
\text { sponsored } \\
\text { patients }\end{array}$ & $\begin{array}{c}\text { Self- } \\
\text { sponsored } \\
\text { patients }\end{array}$ & Total patients \\
\hline $1993-1996$ & 2 & 5 & 7 \\
$1997-2000$ & 2 & 4 & 6 \\
$2001-2004$ & 4 & 4 & 8 \\
$2005-2008$ & 12 & 6 & 18 \\
$2009-2012$ & 9 & 1 & 10 \\
\hline All & 29 & 20 & 49 \\
\hline
\end{tabular}

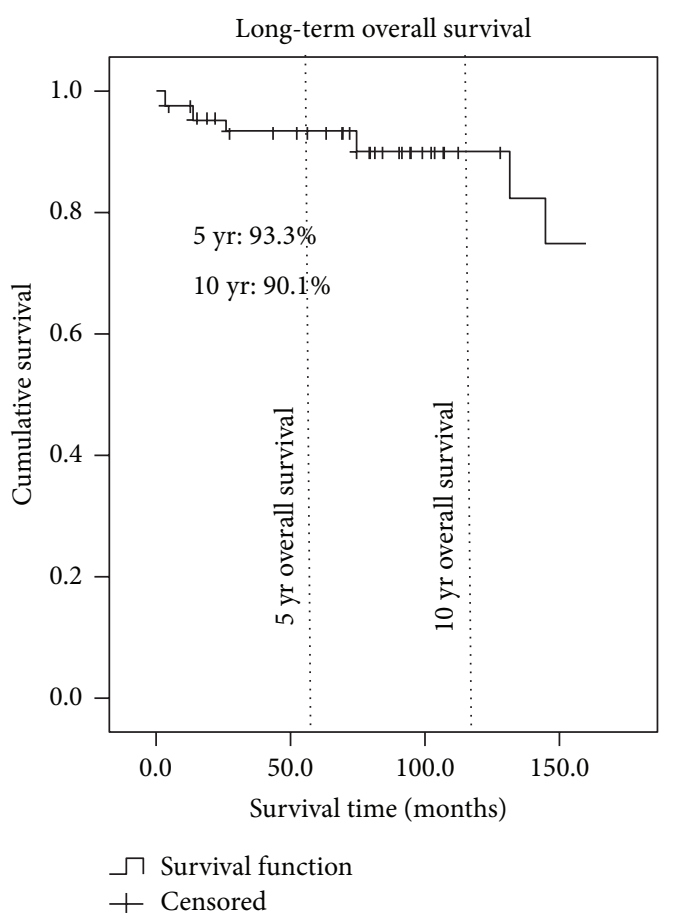

Figure 1: Kaplan-Meier overall patient survival curve of patients after renal transplantation.

were $91.3 \%$ and $91.3 \%$, respectively. Most of the failed grafts for government-sponsored patients were within the first three years of transplant and beyond ten years. The 5- and 10year graft survival for self-sponsored patients was $90.0 \%$ and $70.3 \%$, respectively. There are, however, no statistical differences between the two groups. Figure 3 highlighted the difference between these two groups. The 5-year graft survival for genetically related, spousal, and unrelated transplantations (commercialised) was $92.9 \%, 87.5 \%$, and $90.0 \%$, respectively. There was no statistical difference between these groups.

The 5-year living-related (government-sponsored) patient and graft survival were equivalent to data from Singapore, Malaysia, USA, UK, Australia, and New Zealand. Our 10year graft and patient survival were superior (Table 3 ). The 5- and 10-year commercialised (self-sponsored) patient and graft survival were also equivalent to Singapore and Malaysia

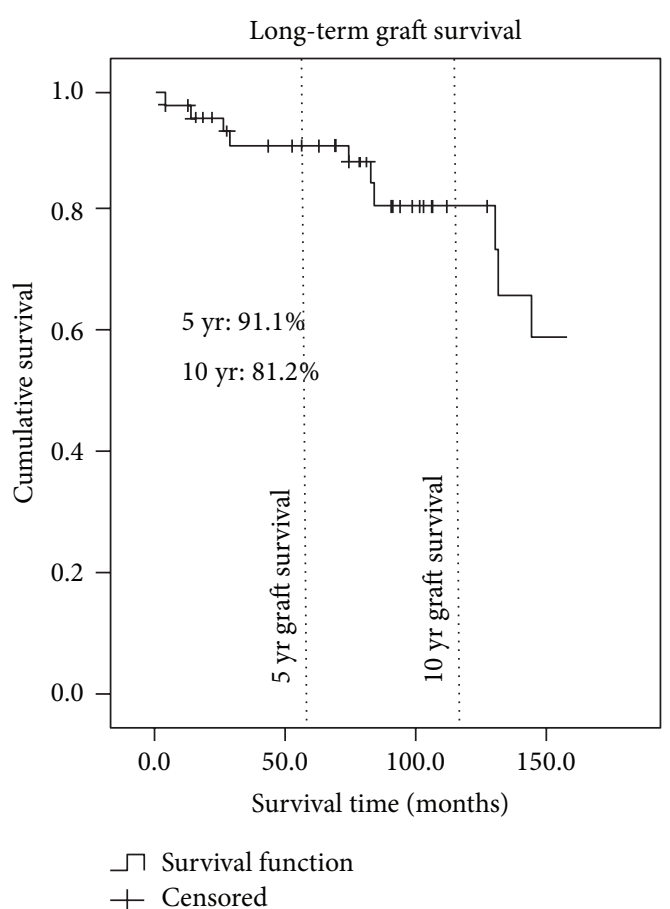

FIGURE 2: Kaplan-Meier graft survival curve of patients after renal transplantation.

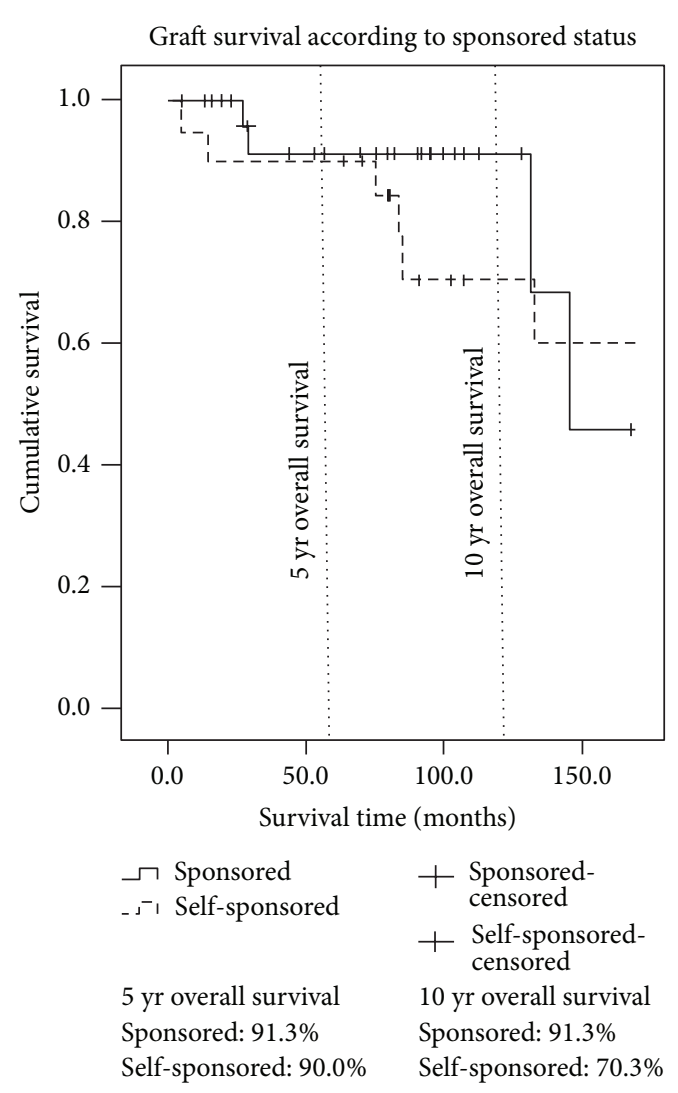

Figure 3: Kaplan-Meier graft survival curves for governmentsponsored and self-sponsored transplantations. 
TABLE 3: Living donor (LD) graft and patient survivals.

\begin{tabular}{|c|c|c|c|c|c|c|c|c|}
\hline Country & Year & Source & Year of transplant & $\begin{array}{c}\text { 5-year graft } \\
\text { survival }\end{array}$ & $\begin{array}{l}\text { 5-year patient } \\
\text { survival }\end{array}$ & $\begin{array}{l}\text { Year of } \\
\text { transplant }\end{array}$ & $\begin{array}{l}\text { 10-year graft } \\
\text { survival }\end{array}$ & $\begin{array}{l}\text { 10-year } \\
\text { patient } \\
\text { survival }\end{array}$ \\
\hline Brunei & 2013 & Tan [1] & 1993-2012 & 91.3 & 95.7 & $1993-2012$ & 91.3 & 95.7 \\
\hline Singapore & 2009 & $\begin{array}{l}\text { Vathsala and } \\
\text { Khuan [4] }\end{array}$ & 1999-2006 & 95.3 & 96.6 & NA & NA & NA \\
\hline Malaysia & 2013 & MDTR [5] & 1993-2012 & 86 & 94 & 1993-2012 & 71 & 88 \\
\hline USA & 2012 & $\begin{array}{c}\text { Organ } \\
\text { Procurement and } \\
\text { Transplantation } \\
\text { Network [6] }\end{array}$ & 2006 & 84 & 93.4 & 2001 & 60.3 & 83 \\
\hline UK & 2012 & $\begin{array}{l}\text { UK Renal Registry } \\
{[7]}\end{array}$ & $2002-2006$ & 91 & 96 & NA & NA & NA \\
\hline $\begin{array}{l}\text { Australia and New } \\
\text { Zealand }\end{array}$ & 2012 & $\begin{array}{l}\text { Australia and New } \\
\text { Zealand Dialysis } \\
\text { and Transplant } \\
\text { Registry [8] }\end{array}$ & 2000-2004 & 87.7 & 94.3 & 2000-2004 & 72.4 & 87.2 \\
\hline
\end{tabular}

but superior to other countries (Saudi Arabia, Iran, Republic of Korea, Turkey, and Pakistan (Table 4)).

\section{Discussion}

Government-sponsored transplant patients were patients that had met the fitness and citizenship eligibility criteria and had a willing donor from their immediate family. These patients were usually sent to Singapore or Malaysia. Selfsponsored patients were those who did not fulfil these criteria and partook in commercialised transplantations. In these instances, there was usually a lack of communication between the foreign transplant centres and the patients tending to be evasive in giving details of the donors (either deceased or living-unrelated). For the purpose of this discussion and easy comparisons with international literature, we will classify government-sponsored patients as living-related transplantations (LD) (Table 3) and nonsponsored patients as commercialised transplantations (Table 4).

Our 5- and 10-year overall graft survival rates were 91.1\% and $81.2 \%$, respectively. The 5- and 10 -year overall patient survivals were $93.3 \%$ and $90.1 \%$, respectively. We believe that these rates were respectable when compared to those achieved in many countries. Our 5-year living donor (LD) graft and patient survival rates were equivalent to those achieved in Singapore [4], where the majority of our governmentsponsored patients (93.3\%) were sent. Our 10-year LD graft and patient survival rates were better than those reported by the Malaysian Dialysis and Transplant Registry (MDTR) [5], Organ Procurement and Transplantation Network (OPTN) [6], UK Renal Registry [7], and ANZ Renal Registry [8]. This could be explained by the greater proportion of younger (median age 32 years) and nondiabetic patients (96.6\%) in our LD transplant population. Patients who are deemed to be with high risk or have complicated medical issues are not sent for transplantation overseas. This means that the average Brunei LD transplant patient is comparatively younger and healthier than the average international transplant patient, which could explain the superior survival rates. Table 3 shows the LD transplantation survival rates of different countries.

Our data did not show any significant survival differences between government-sponsored and self-sponsored (or commercialised) groups. This may indicate that a significant proportion of the kidneys from commercialised transplantation may have been derived from living rather than deceased donors (DD). Similar survival trends were also observed in neighbouring Southeast Asian countries (Singapore and Malaysia) with a significant commercialised kidney transplant population. Vathsala [9] reported a slightly superior survival in the DD transplantations from China when compared to locally performed DD transplantations in Singapore. However this advantage disappeared when DD transplanted patients with primary nonfunction or vascular thrombosis were excluded from the analysis. Morad and Lim [10] reported equivalent survival rates between commercialised $(n=389)$ and noncommercialised patients in Malaysia with no difference in infection rates. More recent data from the MDTR [5] showed a similar trend with a 5-year survival rate of $87 \%$ in commercialised kidney transplants. Similar results also stemmed from studies from Saudi Arabia [11], Iran [12, 13], and Republic of Korea [14]. However, studies from Turkey $[15,16]$ and Pakistan [17] showed inferior rates of patient and graft survival with high rates of complications. Table 4 summarises the graft and patient survival between commercialised and noncommercialised transplants in studies with $>100$ patients in the last twenty years.

The lack of survival differences between the two groups could be explained by several factors. We may not have an accurate representation of early failed commercialised transplants (primary graft failure or venous thrombosis) due to poor or lack of communication with these centres. We also speculate that wealthier, motivated, and educated patients are more likely to seek overseas commercialised transplantations. These patients can usually afford a healthier lifestyle and have access to better private healthcare facilities. They are less likely 
TABLE 4: Commercialised graft and patient survivals.

\begin{tabular}{|c|c|c|c|c|c|c|c|}
\hline Authors & Year & Country & Journal & Number & $\begin{array}{c}\text { Country of } \\
\text { transplant }\end{array}$ & Graft outcome & Patient outcome \\
\hline $\operatorname{Tan}[1]$ & 2013 & Brunei & & 20 & $\begin{array}{l}\text { China, India, } \\
\text { Indonesia, } \\
\text { Philippines }\end{array}$ & $\begin{array}{l}\text { 5- and } 10-\text { year } \\
\text { graft survival at } \\
90 \% \text { and } 70.3 \%\end{array}$ & $\begin{array}{c}5 \text { - and } 10 \text {-year } \\
\text { patient survival } \\
\text { at } 94.5 \% \text { and } \\
83.5 \%\end{array}$ \\
\hline Vathsala [9] & 2010 & Singapore & Clin Transpl & 192 & China, India & $\begin{array}{l}\text { 5- and } 10 \text {-year } \\
\text { graft survivals } \\
\text { for DD } \\
\text { transplants from } \\
\text { China }\end{array}$ & NA \\
\hline $\begin{array}{l}\text { Morad and Lim } \\
{[10]}\end{array}$ & 2000 & Malaysia & Transplant Proc & 389 & Not discussed & $\begin{array}{c}5 \text {-year survival } \\
\text { at } 72 \%\end{array}$ & $\begin{array}{c}5 \text {-year survival } \\
\text { at } 82 \%\end{array}$ \\
\hline MDTR [5] & 2012 & Malaysia & MDTR & & Not discussed & $\begin{array}{c}5 \text {-year graft } \\
\text { survival at } 87 \%\end{array}$ & NA \\
\hline Quinibi [11] & 1997 & Saudi Arabia & Clin Transpl & 540 & India & $\begin{array}{c}5 \text {-year survival } \\
\text { at } 72 \%\end{array}$ & $\begin{array}{c}5 \text {-year survival } \\
\text { at } 92 \%\end{array}$ \\
\hline $\begin{array}{l}\text { Ghods and Savaj } \\
{[12]}\end{array}$ & 2006 & Iran & Clin J Am Soc Nephrol & 1499 & Iran & $\begin{array}{c}\text { Graft } 5 \text { - and } \\
10 \text {-year survival } \\
\text { at } 74.4 \% \text { and } \\
48.8 \% \\
\text { respectively }\end{array}$ & $\begin{array}{c}\text { Patient } 5 \text { - and } \\
10 \text {-year survival } \\
\text { at } 87.1 \% \text { and } \\
72.2 \%\end{array}$ \\
\hline Ghods [13] & 2002 & Iran & Nephrol Dial Transplant & 942 & Iran & $\begin{array}{c}\text { 5- and } 10 \text {-year } \\
\text { survival at } \\
64.2 \% \text { and } \\
43.7 \% \text {, } \\
\text { respectively }\end{array}$ & $\begin{array}{c}\text { 5- and } 10 \text {-year } \\
\text { survival at } \\
83.7 \% \text { and } \\
73.3 \% \text {, } \\
\text { respectively }\end{array}$ \\
\hline Kwon et al. [14] & 2011 & Republic of Korea & J Korean Med Sci & 462 & China & $\begin{array}{l}\text { Survival of } \\
96.5 \% \text { (median } \\
\text { follow-up } 21.2 \\
\text { months) }\end{array}$ & $\begin{array}{c}\text { Survival of } \\
96.8 \% \text { (median } \\
\text { follow-up } 21.2 \\
\text { months) }\end{array}$ \\
\hline Sever et al. [15] & 2001 & Turkey & Kidney Int & 115 & India, Iraq, Iran & $\begin{array}{c}2-, 5-, \text { and } 7-y e a r \\
\text { survival at } 84 \%, \\
66 \% \text {, and } 53 \% \\
\text { respectively }\end{array}$ & $\begin{array}{c}2-, 5-\text {, and } 7-\text { year } \\
\text { survival at } 90 \% \text {, } \\
80 \% \text {, and } 74 \% \text {, } \\
\text { respectively }\end{array}$ \\
\hline $\begin{array}{l}\text { Çolakoğlu et al. } \\
{[16]}\end{array}$ & 1998 & Turkey & Nephron & 127 & India & $\begin{array}{c}5 \text {-year survival } \\
\text { at } 57 \%\end{array}$ & $\begin{array}{c}5 \text {-year survival } \\
\text { at } 92 \%\end{array}$ \\
\hline Rizvi et al. [17] & 2009 & Pakistan & Transpl Int & 126 & Pakistan & $\begin{array}{c}\text { Graft 1- and } \\
5 \text {-year survival } \\
\text { at } 86 \% \text { and } 45 \% \text {, } \\
\text { respectively }\end{array}$ & NA \\
\hline
\end{tabular}

to spend a long time on dialysis and will have avoided the usual dialysis-related atherosclerotic complications that may jeopardise long-term kidney and patient survival. We believe that these factors amongst the self-sponsored patients may have led to misleadingly good outcomes when compared with self-sponsored LD transplants that theoretically should have undergone more stringent cross-matching exercises and had less HLA mismatch.

It is important for us to demonstrate to healthcare providers and patients in the country that renal transplantation is superior to the other modalities of RRT. There has been an undersubscription of renal transplantation as the preferred RRT modality over the past few decades. Between 2008 and 2012 , the country's prevalent RRT population increased by $24 \%$ from 502 to 620 patients. During the same time period, the prevalent renal transplant population increased by only $13 \%$ from 31 to 35 patients [2]. There was a fall in the number of transplants since 2009 which could be related to the difficulties in procuring commercial kidneys in India and China. This could also be through our persistent efforts in educating patients to deter commercialised transplant activities. This is consistent with trends observed in other countries, likely as a result of international efforts to curb illegal transplantations [18]. Our current transplant rate of 9 ppm in 2011 (based on a Brunei population of 422,700 [19]) was low compared to other developed countries like USA (57.5), UK (53.3), and Australia (37.9) [20]. However, our rates were similar to those achieved by other neighbouring Southeast Asian countries like Malaysia (8.3), Singapore (18.5), and Thailand (5.5) [20]. We recognise that this trend is in part due to poor public 
awareness, inadequate cultural acceptance, and the lack of local transplant facilities.

Considering the benefits of renal transplantation, numerous public exercises have been carried out to improve public awareness. A recent public survey succeeded in disseminating information about renal transplantation to the general public [21]. The same survey revealed that $78.7 \%$ of 300 respondents were willing to donate their kidneys if the need arose and $59.7 \%$ of respondents preferred to have transplantation locally. We also conducted a quality of life survey amongst RRT patients which showed that transplant patients had a superior quality of life when compared to $\mathrm{HD}$ and $\mathrm{PD}$ patients in Brunei [22]. This piece of information has been disseminated in public forums and health promotion events to encourage patients and relatives to appreciate the benefits of transplantation. We also intend to use the results of this study to convince the public that equivalent international survival outcomes can be achieved through the practice of legitimate overseas transplant and that the local expertise in the country is capable of monitoring and treating longterm transplant patients. The encouraging results from our recent studies have given extra motivation and drive to local service providers to proliferate and expand the local transplant program to enhance the quality of care given to local ESRD patients.

\section{Conclusion}

Our survival analysis showed noninferior rates compared to those achieved in other countries in both our LD and commercialised transplant populations. We hope to use this information to convince local stakeholders to invest more interest and resources to favour transplantation as the preferred modality of RRT. The favourable transplant outcomes may also help to enhance public awareness and galvanise patients' interest in choosing transplantation over the other modalities of RRT. This study has also provided baseline survival data to enable future comparisons with our fledging local program.

\section{Conflict of Interests}

On behalf of all the authors, Dr. Jackson Tan declares that there is no conflict of interests and that every author meets the criteria for authorship.

\section{References}

[1] J. Tan, "End stage renal disease in Brunei Darussalam-report from the first Brunei Dialysis Transplant Registry (BDTR)," Renal Failure, vol. 35, no. 8, pp. 1101-1104, 2013.

[2] J. Tan, "Renal replacement therapy in Brunei Darussalam: comparing standards with international renal registries," Nephrology, vol. 19, no. 5, pp. 288-295, 2014.

[3] "Medical milestone as first kidney transplant performed," Borneo Bulletin, 2013.

[4] A. Vathsala and Y. C. Khuan, "Renal transplantation in Singapore," Annals of the Academy of Medicine Singapore, vol. 38, no. 4, pp. 291-299, 2009.
[5] Malaysian Dialysis and Transplant Registry, http://www.msn .org.my/.

[6] Organ Procurement and Transplantation Network, http://www .optn.org/data.

[7] UK Renal Registry, http://www.renalreg.com/.

[8] "Australia and New Zealand dialysis and transplant registry," http://www.anzdata.org.au/.

[9] A. Vathsala, "Outcomes for kidney transplants at the National University Health System: comparison with overseas transplants," Clinical Transplants, pp. 149-160, 2010.

[10] Z. Morad and T. O. Lim, "Outcome of overseas kidney transplantation in Malaysia," Transplantation Proceedings, vol. 32, no. 7, pp. 1485-1486, 2000.

[11] W. Qunibi, "Commercially motivated renal transplantation: results in 540 patients transplanted in India," Clinical Transplantation, vol. 11, no. 6, pp. 536-544, 1997.

[12] A. J. Ghods and S. Savaj, "Iranian model of paid and regulated living-unrelated kidney donation," Clinical Journal of the American Society of Nephrology, vol. 1, no. 6, pp. 1136-1145, 2006.

[13] A. J. Ghods, "Renal transplantation in Iran," Nephrology Dialysis Transplantation, vol. 17, no. 2, pp. 222-228, 2002.

[14] C. H. D. Kwon, S.-K. Lee, and J. Ha, "Trend and outcome of Korean patients receiving overseas solid organ transplantation between 1999 and 2005," Journal of Korean Medical Science, vol. 26, no. 1, pp. 17-21, 2011.

[15] M. S. Sever, R. Kazancioglu, A. Yildiz et al., "Outcome of living unrelated (commercial) renal transplantation," Kidney International, vol. 60, no. 4, pp. 1477-1483, 2001.

[16] M. Çolakoğlu, M. Yenicesu, T. Akpolat et al., "Nonrelated livingdonor kidney transplantation: medical and ethical aspects," Nephron, vol. 79, no. 4, pp. 447-451, 1998.

[17] S. A. H. Rizvi, S. A. A. Naqvi, M. N. Zafar et al., "Commercial transplants in local Pakistanis from vended kidneys: a socioeconomic and outcome study," Transplant International, vol. 22, no. 6, pp. 615-621, 2009.

[18] B. Adamu, M. Ahmed, R. F. Mushtaq, and F. Alshaebi, "Commercial kidney transplantation: trends, outcomes and challenges-a single-centre experience," Annals of African Medicine, vol. 11, no. 2, pp. 70-74, 2012.

[19] Data from the Department of Economic Planning and Development, Prime Minister's Office, http://www.depd.gov.bn/.

[20] US Renal Data System, USRDS 2012 Annual Data Report, http://www.usrds.org/.

[21] T. T. Teo, M. M. Hossain, S. Zinna, Y. P. Liew, and J. Tan, "Public opinion on renal transplantation in Brunei Darussalam," Transplantation Proceedings, vol. 43, no. 10, pp. 3599-3603, 2011.

[22] K. Y. Hon, S. Alam, M. Hossain, and J. Tan, "Quality of life comparisons between patients on renal replacement therapy in Brunei Darussalam," Transplantation, vol. 94, no. 10S, pp. 806$807,2012$. 


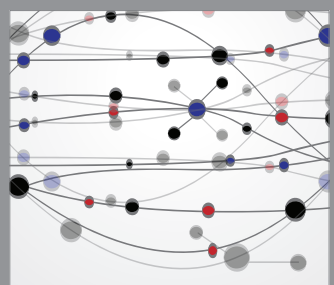

The Scientific World Journal
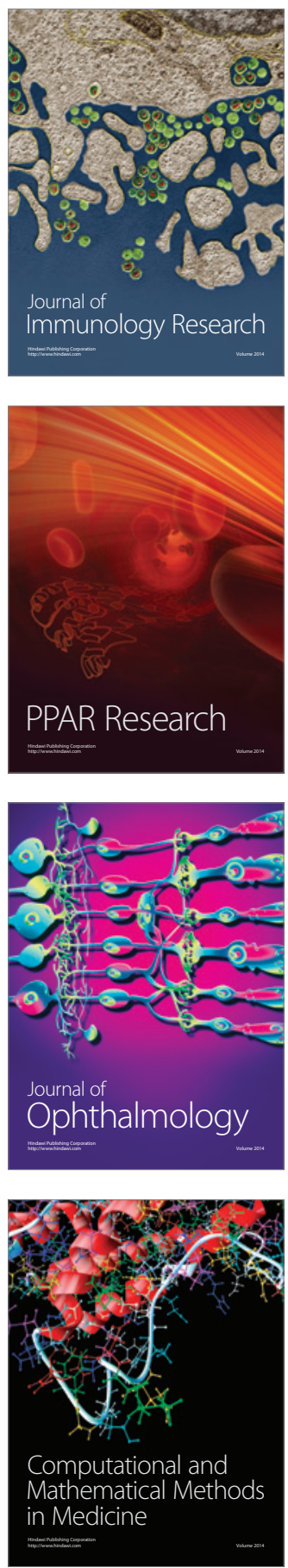

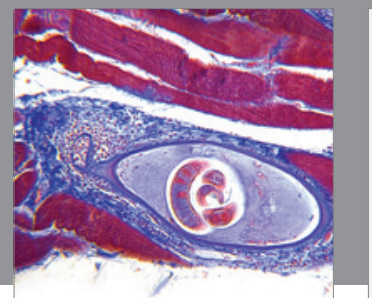

Gastroenterology

Research and Practice
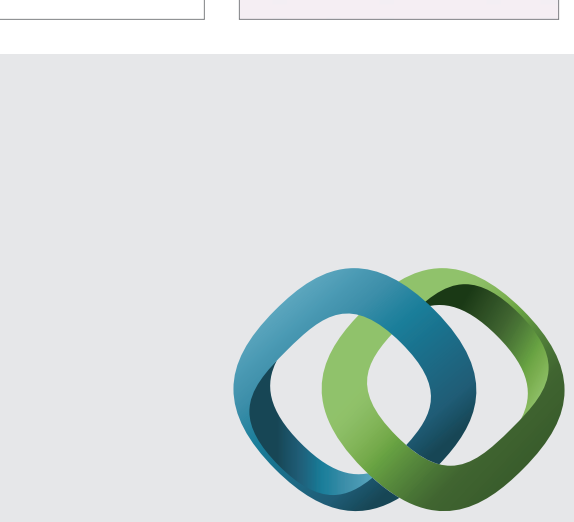

\section{Hindawi}

Submit your manuscripts at

http://www.hindawi.com
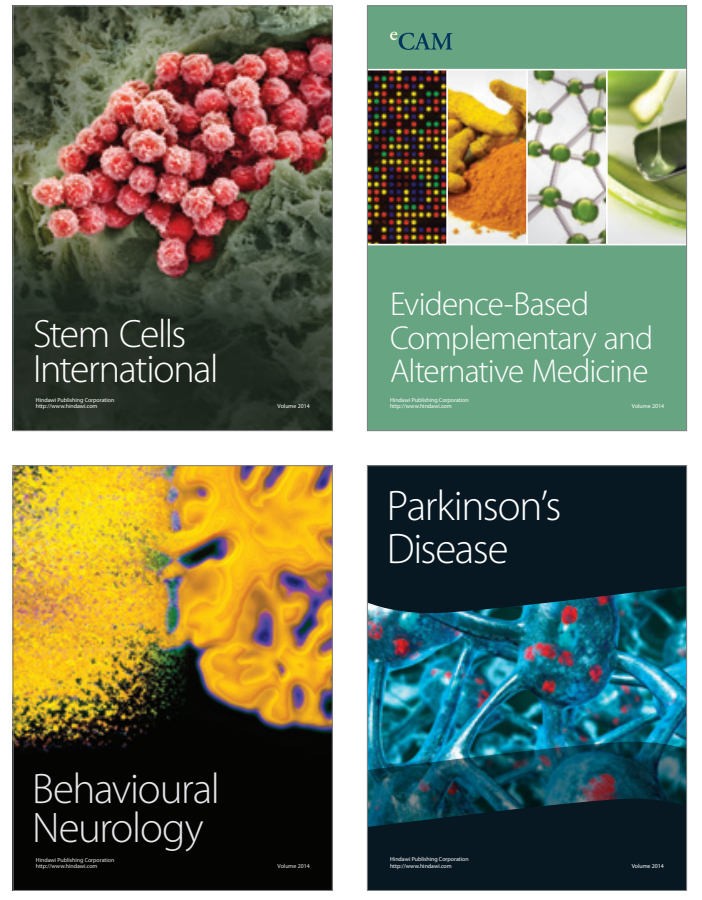
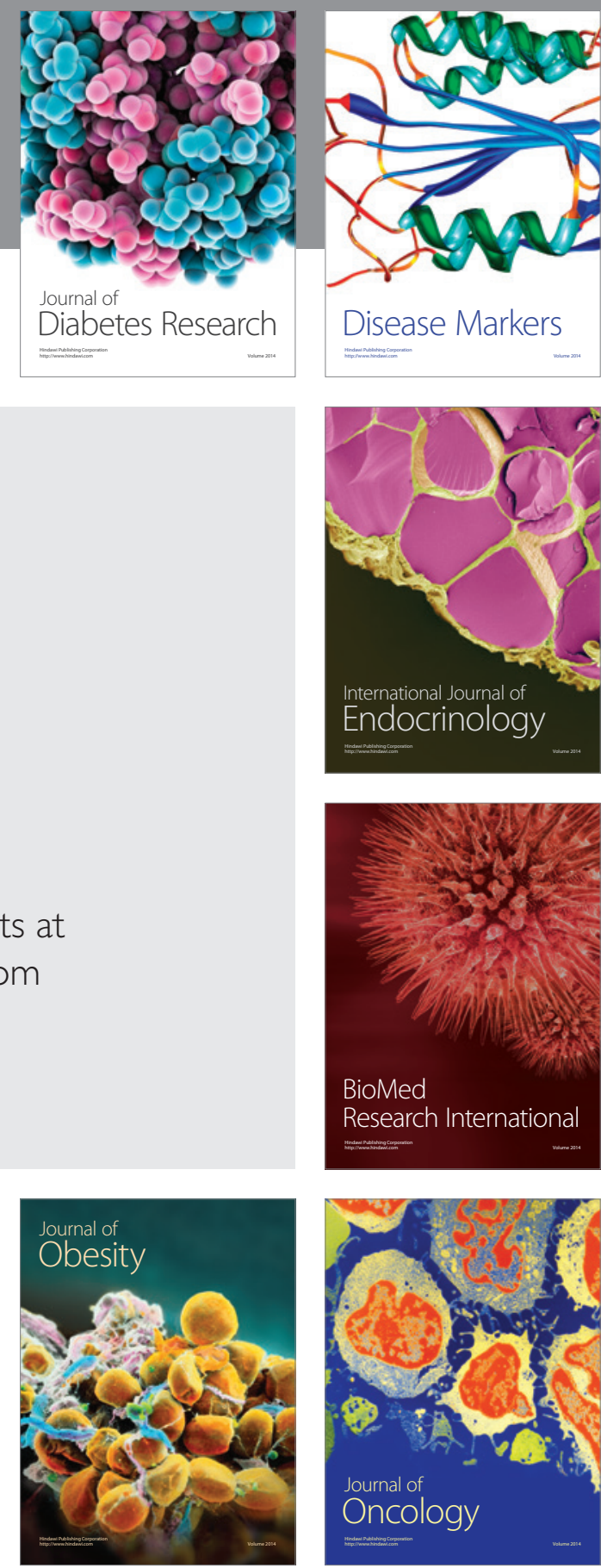

Disease Markers
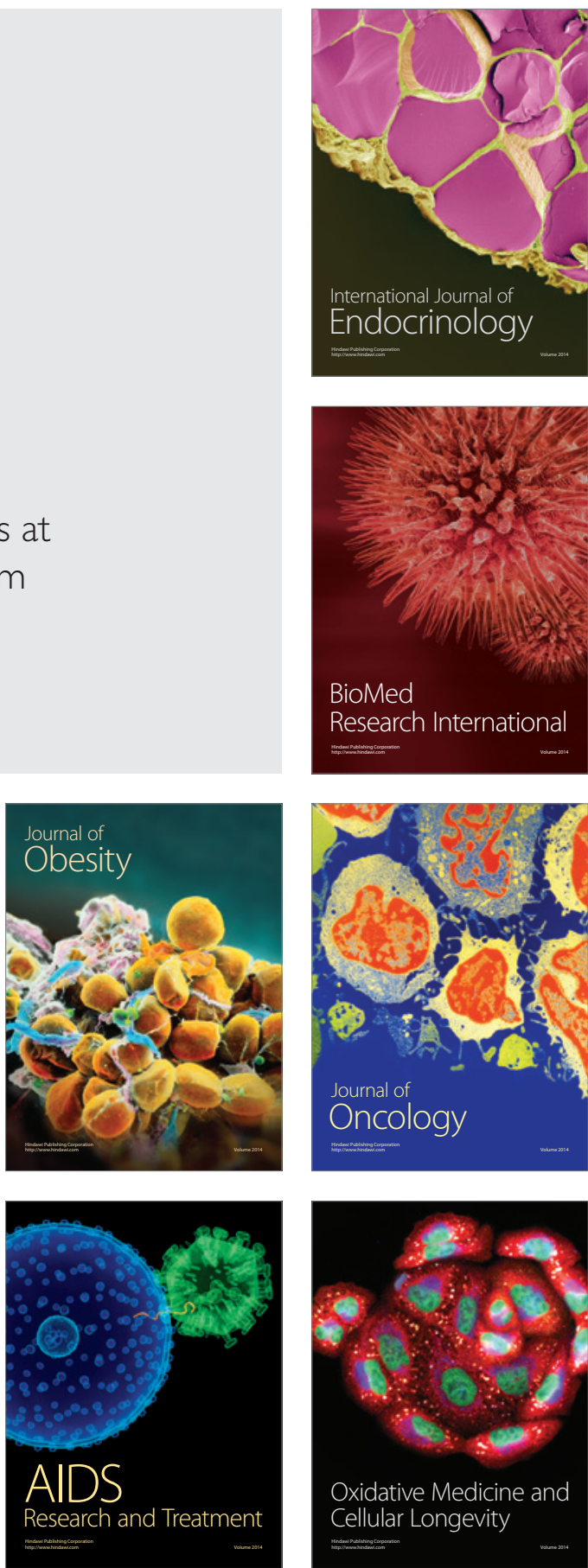